\title{
In vitro Studies of Efficacy of Different Chemicals for Management of Fungal Disease (White Muscardine) and Bacterial Disease (Bacillus and Staphylococcus) in Silk Worm Bombax mori L.
}

\author{
Akhilesh Kumar Kulmitra*, V.B. Sanath Kumar and Raje Gowda \\ Department of Plant Pathology, University of Agricultural Sciences, \\ GKVK, Bangalore-560065, India \\ *Corresponding author
}

\author{
A B S T R A C T
}

\begin{tabular}{|l|}
\hline Ke y w or d s \\
$\begin{array}{l}\text { Beauveria } \\
\text { bassiana, } \\
\text { Bombax mori. }\end{array}$ \\
\hline Article Info \\
\hline $\begin{array}{l}\text { Accepted: } \\
\text { 26 June } 2017 \\
\text { Available Online: } \\
\text { 10 July } 2017\end{array}$ \\
\hline
\end{tabular}

Among the silkworm diseases, white muscardine caused by Beauveria bassiana is the most common disease. The seven different chemicals viz., BKC (90\%), pine Oil (100\%), bleach $(12 \%)$, sodium chlorite $(80 \%)$, bleaching powder $(30 \%)$, sanitech $(2000 \mathrm{ppm})$ and hydrated lime $(80 \%)$ were tested and screened against fungus (beauveria bassiana and bacteria (bacillus and staphyllococcus) based on poison food technique with different concentrations such as $0.05 \%, 0.5 \%, 1 \%, 2 \%, 2.5 \%, 3 \%, 5 \%$ and $10 \%$ with three replications for each chemical concentration along with control. Among all the chemical the $\mathrm{BKC}(90 \%)$ gave better result. all the six concentration viz., 0.5, 1.0, 1.5, 2.5, 5 and 10 were tested against fungus (beauveria bassiana) and bacteria ( bacillus and staphylococcus). The maximum inhibition was recordrd in $10 \%$ concentration of BKC followed by $5 \%$.The minimum inhibition of radial growth of fungus was recorded in Pine oil i.e. $5 \%$ concentration followed by $2.5 \%$.In case of bacterial pathogen 5 and $10 \%$ concentration shows maximum inhibition and $2.5 \%$ concentration shows partial inhibition. In general, the inhibition of radial growth of fungus increased with increase in concentration of each chemical.

\section{Introduction}

Sericulture is an applied branch of science, multi-disciplinary in nature and is rural oriented, practiced more prominently in the tropical countries (Singhvi et al., 1996; Seidavi et al., 2005; Dandin, 2008; Nagaraju, 2008; Ahmed and Rajan, 2011; Anitha, 2011). The mulberry silkworm, Bombyx mori is of great economic importance as a foreign exchange earner for many silk producing countries of the world (Krishnaswami et al., 1992). Silkworm, Bombyx mori L. is an important economic lepidopteron insect and utilized for the commercial production of the natural silk fiber "Queen of Textiles". The silkworm Bombyx mori is prone to various pests and diseases. Diseases in the silkworm Bombyx mori are fairly common in occurrence and are serious in inflicting cocoon crop loss. These can be grouped under four major categories, namely the microsporidian disease, viral diseases, bacterial diseases, and fungal diseases. Among the diseases of silkworm, white muscardine caused by Beauveria bassiana inflicts heavy economic loss to the sericulturists in India. 
Beauveria bassiana is an entomopathogenic hypomycetes fungus,distributed all over the world.it infects over 100 different insect species coming fromseveral insect orders. In silk worm bombax mori, it causes white muscardine disease infecting significant crop loss in all sericulture countries. Muscardine is one of the contagious diseases, which is causing loss of 5-50 per cent in total loss due to diseases (Hanumappa, 1986).

The fungus infects silkworm under favorable condition through the integument,enters hemocoel, and produce hyphal bodies and parasitise various tissues leading to death of the hosts.after death, the fungus grows saprophitically and forms mycellial mass that turns the host body into hard structure. the conidiophores emerges from the host body and produce infectious conidia (Datta et al., 1998).

Symptoms of muscardine includes loss of appetite, sluggishness of the worms, increased rate of dorsal heart beat, inactiveness of worms, larvae become pale in colour, vomiting, diarrhea and decreased elasticity of the larval body. The larval corpse turns pink or reddish in colour due to the secondary invasion.

Several chemical formulations have been developed to prevent the germination of conidia on the integument and its entry into host body (Samson et al., 1986; Sashidharan et al., 1997).

The microbes were gram positive, rod shaped bacteria (Bacillus spp.), cocci shaped (Staphylococcus spp.) and gram negative (Sengupta et al., 1990).

\section{Materials and Methods}

In vitro studies of efficacy of different chemicals for control of fungal disease (white muscardine) and bacterial disease (bacillus and staphylococcus) in silk worm bombax mori L. was carried out during 2015 at the Department of Sericulture, KVK, University of Agricultural Sciences, GKVK, Bangalore.

The diseased silkworms were collected from field, and fungus and bacteria were isolated in the pure form (Govindan et al., 1998). A small bit of mycellium of Beauveria bassiana was incorporated into poisonated potato dextrose agar media (PDA) and incubated at $26 \pm 1^{\circ} \mathrm{C}$ for a period of 15 days and was observed for the growth of fungus. The growth of fungus was quantified visually as -: negative; \pm : negligible; + : satisfactory growth; ++ : good growth; and +++: very good growth. (Plate no. 1 to 3 )

For bacteria to obtain samples from silk worm, the insect was surface sterilized in $70 \%$ ethanol and washed 3 times with sterile distilled water. The insects were then triturated in sterile water blanks using glass rod. The suspension was serially diluted up to $10^{-6}$ then $0.1 \mathrm{ml}$ of the suspension was inoculated into nutrient agar using the streak plate method and incubated at $26^{\circ} \mathrm{C}$ for $24 \mathrm{~h}$.

This set up was observed for colony growths and the total number of colonies observed was recorded to determine the standard plate count from 3 replicates. Distinct colonies were subsequently isolated for further analysis, and different chemical concentrations were prepared and added to the Nutrient Agar (NA) medium. A loop of bacterial culture was drawn from culture of Bacillus sp. and were streaked on the plates and kept for incubation. Observations were made on the growth after 48 hours quantified visually as \pm Partial inhibition, + No inhibition, - Inhibition.

Seven different chemicals viz., BKC (90\%), pine Oil (100\%), bleach (12\%), sodium chlorite (80\%), bleaching powder (30\%), sanitech (2000ppm) and hydrated lime (80\%) were tested and screened them against fungus 
(Beauveria bassiana and bacteria (bacillus and Staphylococcus). The in vitro screening of the seven chemicals was performed based on poison food technique with different concentrations such as $0.05 \%, 0.5 \%, 1 \%, 2 \%$, $2.5 \%, 3 \%, 5 \%$ and $10 \%$. There were three replications for each chemical concentration maintained along with control (Table 1).

\section{Results and Discussion}

The silkworm showed symptoms of white muscardine, it was inferred that the fungus could be Beauveria bassiana, the most common one causing white muscardine in India (Chandrasekaran and Nataraju, 2008).

Efficacy of Seven different chemicals viz., BKC (90\%), pine Oil (100\%), bleach (12\%), sodium chlorite (80\%), bleaching powder (30\%), sanitech (2000ppm) and hydrated lime $(80 \%)$ were tested and screened them against fungus (Beauveria bassiana and bacteria (bacillus and Staphylococcus). The in vitro screening of the seven chemicals was performed based on poison food technique with different concentrations such as $0.05 \%$, $0.5 \%, 1 \%, 1.5,2 \%, 2.5 \%, 3 \%, 5 \%$ and $10 \%$ ). Three replications for each chemical concentration maintained along with control. The results thus obtained have been presented in table $2 \mathrm{a}$ to $8 \mathrm{~b}$ and depicted.

In table $2 \mathrm{a}$ and $2 \mathrm{~b}$ the different concentration of BKC chemical such as 0.5, 1.0, 2.5, 5.0 and $10 \%$ tested among all these concentrations the highest inhibition of radial growth of fungus were recorded in $2.5 \%$ (0 $\mathrm{cm}), 5 \%(0 \mathrm{~cm})$ and $10 \%(0 \mathrm{~cm})$ concentration. The minimum inhibition of radial growth of fungus was recorded in $1.5 \%(0.36 \mathrm{~cm}), 1 \%$ $(0.6 \mathrm{~cm})$ and $0.5 \%(0.95 \mathrm{~cm})$ concentration. In case of bacterial pathogen $5 \%$ and $10 \%$ concentration showed maximum inhibition and $0.5,1.0$ and $1.5 \%$ concentration showed partial inhibition.
In table $3 \mathrm{a}$ and $3 \mathrm{~b}$ the different concentration of Pine oil were tested in different concentration such as 2.5, 5 and $10 \%$ among all these concentrations the highest inhibition of radial growth of fungus were recorded in $10 \%(0 \mathrm{~cm})$ concentration. The minimum inhibition of radial growth of fungus was recorded in $5 \%(0.63 \mathrm{~cm})$ followed by $2.5 \%$ $(0.95 \mathrm{~cm})$. In case of bacterial pathogen 5 and $10 \%$ concentration shows maximum inhibition and $2.5 \%$ concentration shows partial inhibition.

In table $4 \mathrm{a}$ and $4 \mathrm{~b}$ the different concentration of Bleach were tested in different concentration such as $0.5,1,2.5,5$ and $10 \%$ among all these concentrations the highest inhibition of radial growth of fungus were recorded in $10 \%(0 \mathrm{~cm}), 5 \%(0 \mathrm{~cm})$ and $2.5 \%(0 \mathrm{~cm})$ concentration. The minimum inhibition of radial growth of fungus was recorded in $0.5 \%(0.63 \mathrm{~cm})$ followed by 0.5 $\%(0.95 \mathrm{~cm})$.In case of bacterial pathogen 1 , $2.5,5$ and $10 \%$ concentration shows maximum inhibition and $0.5 \%$ concentration shows partial inhibition.

In table $5 \mathrm{a}$ and $5 \mathrm{~b}$ the different concentration of Sodium chlorite was tested in different concentration such as 1,2 and 3\% among all these concentrations the highest inhibition of radial growth of fungus were recorded in $2 \%$ $(0 \mathrm{~cm})$ followed by $\%(0 \mathrm{~cm})$. The minimum inhibition of radial growth of fungus was recorded in $1 \%(0.95 \mathrm{~cm})$. In case of bacterial pathogen $2 \%$ and $3 \%$ concentration shows maximum inhibition and $1 \%$ concentration shows partial inhibition.

In table $6 \mathrm{a}$ and $6 \mathrm{~b}$ the different concentration of Bleaching Powder was tested in different concentration such as 1 and $2 \%$ among all these concentrations the highest inhibition of radial growth of fungus were recorded in $2 \%$ $(0 \mathrm{~cm})$. The minimum inhibition of radial growth of fungus was recorded in $1 \%$ 
$(0.95 \mathrm{~cm})$. In case of bacterial pathogen $3 \%$ concentration shows maximum inhibition and $1 \%$ concentration shows partial inhibition (Subba Rao et al., 1992). In table 7a and 7b the $1 \%$ concentration of Sanitech was tested and shows complete inhibition of radial growth of fungus $(0 \mathrm{~cm})$.In case of bacterial pathogen $1 \%$ concentration shows complete inhibition.

Table.1 List of chemicals used for in vitro evaluation against Beauveria bassiana, Bacillus and Staphylococcus

\begin{tabular}{clccccc}
\hline S NO. & \multicolumn{1}{c}{ Chemicals } & \multicolumn{5}{c}{ Concentrations (\%) } \\
\hline $\mathbf{1}$ & $\begin{array}{l}\text { Benzo Conium Chloride } \\
\text { (BKC) (90\%) }\end{array}$ & 2.5 & 5 & 10 & - & - \\
$\mathbf{2}$ & Pine oil (100\%) & 2.5 & 5 & 10 & & \\
$\mathbf{3}$ & Bleach (12\%) & 0.5 & 1 & 2.5 & 10 & - \\
$\mathbf{4}$ & Sodium chlorite (80\%) & 1 & 2 & 3 & - & - \\
$\mathbf{5}$ & Bleaching powder (30\%) & 1 & 2 & - & - & - \\
$\mathbf{6}$ & Sanitech (2000ppm) & 0.05 & - & - & - & - \\
$\mathbf{7}$ & Hydrated lime (80\%) & 1 & 2 & - & - & - \\
\hline
\end{tabular}

Table.2a In vitro screening of BKC on Beauveria bassiana by poison food technique

\section{DAI Concentration $(\%)$ of chemical (BKC) and growth of control fungus}

\begin{tabular}{ccccc}
\cline { 2 - 3 } $\mathbf{1}$ & $\mathbf{2 . 5}$ & $\mathbf{5}$ & $\mathbf{1 0}$ & \\
$\mathbf{3}$ & \pm & \pm & \pm & $\pm(0.6 \mathrm{~mm})$ \\
$\mathbf{5}$ & \pm & \pm & \pm & $+(1.8 \mathrm{~mm})$ \\
$\mathbf{7}$ & \pm & \pm & \pm & $+(2.1 \mathrm{~mm})$ \\
$\mathbf{9}$ & \pm & \pm & \pm & $++(3.2 \mathrm{~mm})$ \\
11 & \pm & \pm & \pm & $++(3.6 \mathrm{~mm})$ \\
$\mathbf{1 3}$ & \pm & \pm & \pm & $+++(3.9 \mathrm{~mm})$ \\
15 & \pm & \pm & \pm & $+++(4.2 \mathrm{~mm})$ \\
\hline
\end{tabular}

-: negative; \pm :negligible; +:satisfactory growth; ++:good growth; and +++:very good growth. 
Table.2b In vitro screening of BKC on Bacillus and Staphylococcus by streak plate method

\begin{tabular}{|c|c|c|c|c|}
\hline \multirow[t]{2}{*}{ DAI } & \multicolumn{3}{|c|}{$\begin{array}{c}\text { Concentration(\%) of chemical (BKC) and growth of } \\
\text { bacteria }\end{array}$} & \multirow[t]{2}{*}{ control } \\
\hline & 2.5 & 5 & 10 & \\
\hline 1 & \pm & - & - & + \\
\hline 3 & \pm & - & - & + \\
\hline 5 & \pm & - & - & + \\
\hline 7 & \pm & - & - & + \\
\hline 9 & \pm & - & - & + \\
\hline 11 & \pm & - & - & + \\
\hline 13 & \pm & - & - & + \\
\hline 15 & \pm & - & - & + \\
\hline
\end{tabular}

\pm Partial inhibition, + No inhibition, - Inhibition

Table.3a In vitro screening of pine oil on Beauveria bassiana by poison food technique

\begin{tabular}{|c|c|c|c|c|}
\hline \multirow[t]{2}{*}{ DAI } & \multicolumn{3}{|c|}{$\begin{array}{l}\text { Concentration(\%) of chemical (BKC) and growth of } \\
\text { fungus }\end{array}$} & \multirow[t]{2}{*}{ control } \\
\hline & 2.5 & 5 & 10 & \\
\hline 1 & \pm & \pm & \pm & $\pm(0.6 \mathrm{~mm})$ \\
\hline 3 & \pm & \pm & \pm & $+(1.8 \mathrm{~mm})$ \\
\hline 5 & \pm & \pm & \pm & $+(2.1 \mathrm{~mm})$ \\
\hline 7 & \pm & \pm & \pm & $++(3.2 \mathrm{~mm})$ \\
\hline 9 & \pm & \pm & \pm & $++(3.6 \mathrm{~mm})$ \\
\hline 11 & \pm & \pm & \pm & $+++(3.9 \mathrm{~mm})$ \\
\hline 13 & \pm & \pm & \pm & $+++(4.2 \mathrm{~mm})$ \\
\hline 15 & \pm & \pm & \pm & $+++(4.2 \mathrm{~mm})$ \\
\hline
\end{tabular}

-: negative; \pm :negligible; +: satisfactory growth; ++: good growth; and +++: very good growth. 
Table.3b In vitro screening of BKC on Bacillus and Staphylococcus by streak plate method

\begin{tabular}{ccccc}
\hline DAI & \multicolumn{3}{c}{ Concentration $(\%)$ of chemical (pine oil) and growth of } & control \\
bacteria & & & \\
\cline { 2 - 5 } 1 & 2.5 & 5 & 10 & + \\
3 & \pm & - & - & + \\
5 & \pm & - & - & + \\
7 & \pm & - & - & + \\
9 & \pm & - & - & + \\
11 & \pm & - & - & + \\
13 & \pm & - & - & + \\
15 & \pm & - & - & + \\
\hline
\end{tabular}

\pm Partial inhibition, + No inhibition, - Inhibition.

Table.4a In vitro screening of bleach on Beauveria bassiana by poison food technique

\begin{tabular}{rcccccc}
\hline DAI & \multicolumn{7}{l}{ Concentration(\%) of chemical (bleach) and growth of fungus } & $\begin{array}{c}\text { control } \\
(\mathbf{m m})\end{array}$ \\
\cline { 2 - 7 } & $\mathbf{0 . 5}$ & $\mathbf{1}$ & $\mathbf{2 . 5}$ & $\mathbf{5}$ & $\mathbf{1 0}$ & \\
$\mathbf{3}$ & \pm & \pm & \pm & \pm & \pm & $\pm(0.6 \mathrm{~mm})$ \\
$\mathbf{5}$ & \pm & \pm & \pm & \pm & \pm & $+(1.8 \mathrm{~mm})$ \\
7 & \pm & \pm & \pm & \pm & \pm & $+(2.1 \mathrm{~mm})$ \\
$\mathbf{9}$ & \pm & \pm & \pm & \pm & \pm & $++(3.2 \mathrm{~mm})$ \\
11 & \pm & \pm & \pm & \pm & \pm & $++(3.6 \mathrm{~mm})$ \\
13 & \pm & \pm & \pm & \pm & \pm & $+++(3.9 \mathrm{~mm})$ \\
15 & \pm & \pm & \pm & \pm & \pm & $+++(4.2 \mathrm{~mm})$ \\
\hline
\end{tabular}

-: negative; \pm :negligible; +: satisfactory growth; ++: good growth; and +++: very good growth. 
Table.4b In vitro screening of bleach on Bacillus and Staphylococcus by streak plate method

\begin{tabular}{ccccccc}
\hline DAI & \multicolumn{9}{c}{ Concentration(\%) of chemical (bleach) and growth of fungus } & control \\
\cline { 2 - 6 } 1 & 0.5 & 1 & 2.5 & 5 & 10 & + \\
3 & \pm & - & - & - & - & + \\
5 & \pm & - & - & - & - & + \\
7 & \pm & - & - & - & - & + \\
9 & \pm & - & - & - & - & + \\
11 & \pm & - & - & - & - & + \\
13 & \pm & - & - & - & - & + \\
15 & \pm & - & - & - & - & + \\
\hline
\end{tabular}

\pm Partial inhibition, + No inhibition, - Inhibition.

Table.5a In vitro screening of sodium chlorite on Beauveria bassiana by poison food technique

\begin{tabular}{|c|c|c|c|c|}
\hline \multirow[t]{2}{*}{ DAI } & \multicolumn{3}{|c|}{$\begin{array}{l}\text { Concentration(\%) of chemical (sodium chlorite) and growth of } \\
\text { fungus }\end{array}$} & \multirow[t]{2}{*}{$\begin{array}{c}\text { control } \\
(\mathbf{m m})\end{array}$} \\
\hline & 1 & 2 & 3 & \\
\hline $\mathbf{1}$ & \pm & \pm & \pm & $\pm(0.6 \mathrm{~mm})$ \\
\hline 3 & \pm & \pm & \pm & $+(1.8 \mathrm{~mm})$ \\
\hline 5 & \pm & \pm & \pm & $+(2.1 \mathrm{~mm})$ \\
\hline 7 & \pm & \pm & \pm & $++(3.2 \mathrm{~mm})$ \\
\hline 9 & \pm & \pm & \pm & $++(3.6 \mathrm{~mm})$ \\
\hline 11 & \pm & \pm & \pm & $+++(3.9 \mathrm{~mm})$ \\
\hline 13 & \pm & \pm & \pm & $+++(4.2 \mathrm{~mm})$ \\
\hline 15 & \pm & \pm & \pm & $+++(4.2 \mathrm{~mm})$ \\
\hline
\end{tabular}

-: negative; \pm :negligible; +: satisfactory growth; ++: good growth; and +++: very good growth 
Table.5b In vitro screening of sodium chlorite on Bacillus and Staphylococcus by streak plate method

\begin{tabular}{lcccc}
\hline DAI & Concentration $(\%)$ of chemical (sodium chlorite) and growth of & control \\
& & & & \\
& $\mathbf{1}$ & 2 & 3 & + \\
$\mathbf{1}$ & \pm & - & - & + \\
3 & \pm & - & - & + \\
$\mathbf{5}$ & \pm & - & - & + \\
7 & \pm & - & - & + \\
9 & \pm & - & - & + \\
11 & \pm & - & - & + \\
13 & \pm & - & - & + \\
15 & \pm & - & - & + \\
\hline
\end{tabular}

\pm Partial inhibition, + No inhibition, - Inhibition

Table.6a In vitro screening of bleaching powder on Beauveria bassiana by poison food technique

\begin{tabular}{cccc}
\hline DAI & $\begin{array}{l}\text { Concentration( \%) of chemical (bleaching powder ) and growth of } \\
\text { fungus }\end{array}$ & $\mathbf{1}$ & $\begin{array}{c}\text { control } \\
(\mathbf{m m})\end{array}$ \\
$\mathbf{1}$ & \pm & $\mathbf{2}$ & \\
$\mathbf{3}$ & \pm & \pm & $\pm(0.6 \mathrm{~mm})$ \\
$\mathbf{5}$ & \pm & \pm & $+(1.8 \mathrm{~mm})$ \\
$\mathbf{7}$ & \pm & \pm & $+(2.1 \mathrm{~mm})$ \\
$\mathbf{9}$ & \pm & \pm & $++(3.2 \mathrm{~mm})$ \\
$\mathbf{1 1}$ & \pm & \pm & $++(3.6 \mathrm{~mm})$ \\
$\mathbf{1 3}$ & \pm & \pm & $+++(3.9 \mathrm{~mm})$ \\
$\mathbf{1 5}$ & \pm & \pm & $+++(4.2 \mathrm{~mm})$ \\
\hline
\end{tabular}

-: negative; \pm :negligible; +: satisfactory growth; ++: good growth; and +++: very good growth 
Table.6b In vitro screening of bleaching powder on Bacillus and Staphylococcus by streak plate method

\begin{tabular}{cccc}
\hline DAI & $\begin{array}{l}\text { Concentration }(\%) \text { of chemical (bleaching powder ) and growth of } \\
\text { bacteria }\end{array}$ & 1 & control \\
& \pm & 2 & + \\
1 & \pm & - & + \\
3 & \pm & - & + \\
5 & \pm & - & + \\
7 & \pm & - & + \\
9 & \pm & - & + \\
11 & \pm & - & + \\
13 & \pm & - & + \\
\hline
\end{tabular}

Table.7a In vitro screening of sanitech on Beauveria bassiana by poison food technique

\begin{tabular}{ccc}
\hline DAI & Concentration(\%) of chemical (sanitech ) and growth of fungus & $\begin{array}{c}\text { control } \\
(\mathbf{m m})\end{array}$ \\
$\mathbf{1}$ & $\mathbf{1}$ & \pm \\
$\mathbf{3}$ & \pm & $\pm(0.6 \mathrm{~mm})$ \\
$\mathbf{5}$ & \pm & $+(1.8 \mathrm{~mm})$ \\
$\mathbf{7}$ & \pm & $+(2.1 \mathrm{~mm})$ \\
$\mathbf{9}$ & \pm & $++(3.2 \mathrm{~mm})$ \\
$\mathbf{1 1}$ & \pm & $++(3.6 \mathrm{~mm})$ \\
$\mathbf{1 3}$ & \pm & $+++(3.9 \mathrm{~mm})$ \\
15 & \pm & $+++(4.2 \mathrm{~mm})$ \\
& & $+++(4.2 \mathrm{~mm})$ \\
\hline$-:$ negative; \pm :negligible; $+:$ satisfactory growth; $++:$ good growth; and $+++:$ very good growth
\end{tabular}


Table.7b In vitro screening of sanitech on Bacillus and Staphylococcus by streak plate method

\begin{tabular}{|c|c|c|}
\hline DAI & $\begin{array}{c}\text { Concentration }(\%) \text { of chemical (sanitech ) and growth of } \\
\text { bacteria }\end{array}$ & control \\
\hline & 1 & \\
\hline 1 & - & + \\
\hline 3 & - & + \\
\hline 5 & - & + \\
\hline 7 & - & + \\
\hline 9 & - & + \\
\hline 11 & - & + \\
\hline 13 & - & + \\
\hline 15 & - & + \\
\hline
\end{tabular}

\pm Partial inhibition, + No inhibition, - Inhibition

Table.8a In vitro screening of lime on Beauveria bassiana by poison food technique

\begin{tabular}{|c|c|c|c|}
\hline \multirow[t]{2}{*}{ DAI } & \multicolumn{2}{|c|}{ Concentration $(\%)$ of chemical (lime ) and growth of fungus } & \multirow{2}{*}{$\begin{array}{c}\text { control } \\
(\mathbf{m m})\end{array}$} \\
\hline & 1 & 2 & \\
\hline 1 & \pm & \pm & $\pm(0.6 \mathrm{~mm})$ \\
\hline 3 & \pm & \pm & $+(1.8 \mathrm{~mm})$ \\
\hline 5 & \pm & \pm & $+(2.1 \mathrm{~mm})$ \\
\hline 7 & \pm & \pm & $++(3.2 \mathrm{~mm})$ \\
\hline 9 & \pm & \pm & $++(3.6 \mathrm{~mm})$ \\
\hline 11 & \pm & \pm & $+++(3.9 \mathrm{~mm})$ \\
\hline 13 & \pm & \pm & $+++(4.2 \mathrm{~mm})$ \\
\hline 15 & \pm & \pm & $+++(4.2 \mathrm{~mm})$ \\
\hline
\end{tabular}

-: negative; \pm :negligible; +: satisfactory growth; ++: good growth; and +++: very good growth 
Table.8b In vitro screening of lime on Bacillus and Staphylococcus by streak plate method

\section{DAI Concentration(\%) of chemical (lime ) and growth of bacteria}

1
3
5
7
9

11

13

15

1
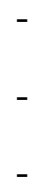

\pm Partial inhibition, + No inhibition, - Inhibition

Plate.1 Diseased silk worm larvae
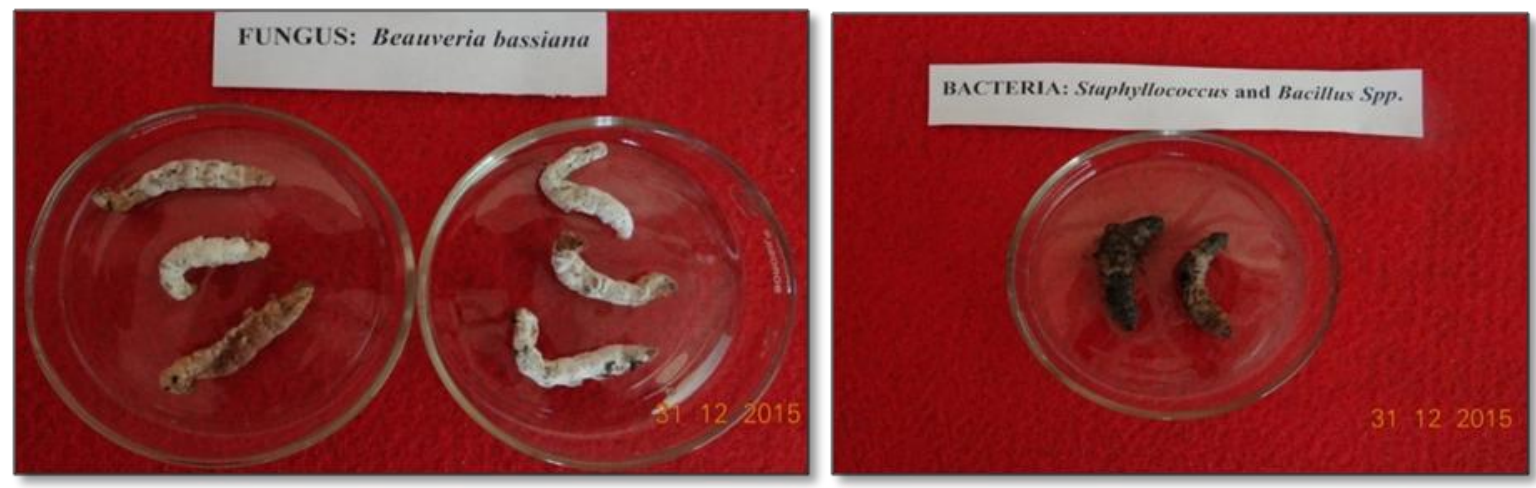

Plate.2 Pure culture of Fungus (Beauveria bassiana)

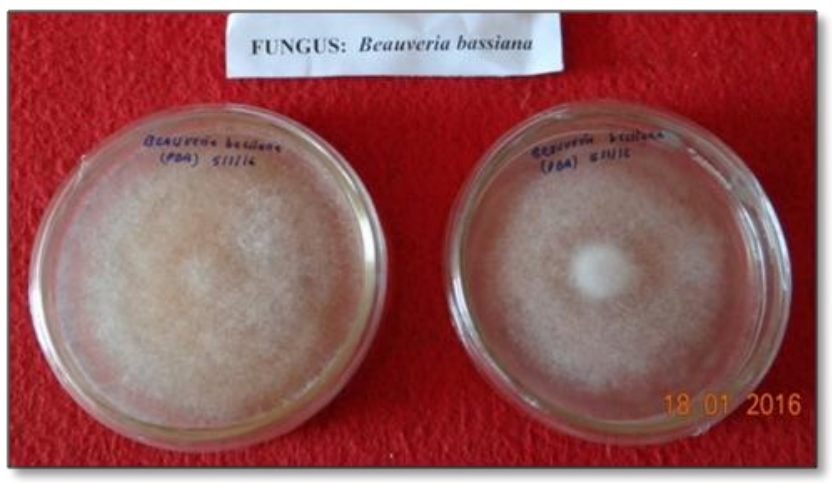




\section{Plate.3 Pure culture of bacteria (Bacillus and Staphylococcus)}

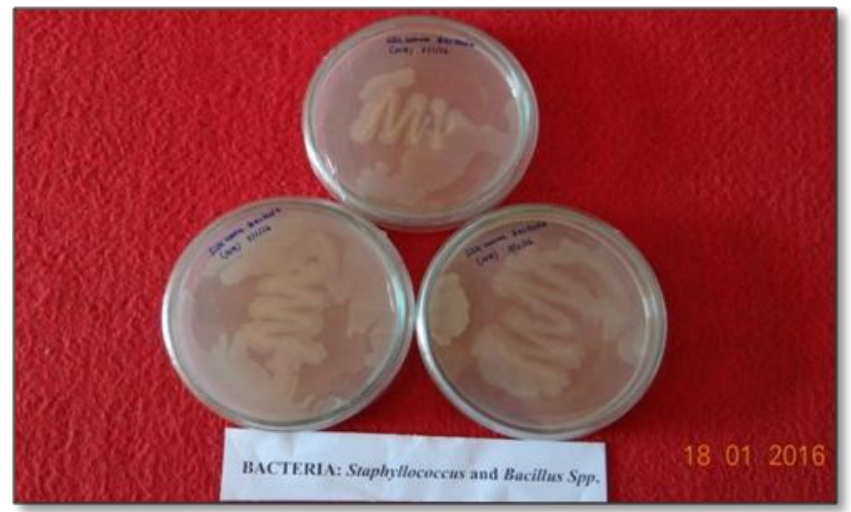

In table $8 \mathrm{a}$ and $8 \mathrm{~b}$ the different concentration of lime was tested in different concentration such as 1 and $2 \%$ among all these concentrations the highest inhibition of radial growth of fungus were recorded in both 1 and $2 \%(0 \mathrm{~cm})$. In case of bacterial pathogen both 1 and $2 \%$ concentration shows complete inhibition (Rangaswamy et al., 2003).

Among all the chemical the BKC $(90 \%)$ gave better result. In BKC all the six concentration viz., $0.5,1.0,1.5,2.5,5$ and 10 were tested against fungus (Beauveria bassiana) and bacteria (bacillus and staphylococcus) the result sows that when concentration increases the per cent inhibition of pathogen also increases the maximum inhibition was recordrd in $10 \%$ concentration of $\mathrm{BKC}$ followed by $5 \%$.

If the diseases are controlled below the economic threshold level then there will be an increase of 25 per cent silk production without any increase in the area under mulberry sericulture (Nagarajan and Radha, 1990).

\section{Acknowledgements}

The support extended by the directorate of research of University of Agricultural Sciences, GKVK, Bangalore, Karnataka, India and the encouragement of the
Management given by V. B. Sanath Kumar, Programme Co-ordinator are gratefully acknowledged.

\section{References}

Ahmed, S.A., and Rajan, R.K. 2011. Exploration of Vanya silk biodiversity in north eastern region of India: Sustainable livelihood and poverty alleviation. Proceedings of the International Conference on Management, Economics and Social Sciences, 11: 485-489.

Anitha, P. 1989. Investigation on the aspergillosis of mulberry silkworm with special reference to its control. M.Sc. (Seri), Thesis, UAS, Bangalore, India. pp. 62-64.

Chandrasekaran, K., and Nataraju, B. 2008. Studies on white muscardine disease of mulberry silkworm, Bombyx mori L. in India- A review. Indian J. Seric., 47(2): 136-154.

Dandin, S.B. 2008. Large scale farming sericulture: A field reality. Indian Silk, 46: $16-20$.

Datta, R.K., Baig, M., Nataraju, B., Balavenkatasubbaiah, M. and Selvakumar, T. 1998. Vijetha, an effective disinfectant. Indian Silk, 1: 1213.

Hanumappa, H.G. 1986. Sericulture for rural 
development. Himalaya Publishing House, Bombay, India.

Krishnaswami, S., Narashimanna, Suyananrayana, S.K. and Kumararaj, S. 1992. Sericulture Manual 2: Silkworm Rearing, Oxford and IBH, New Delhi. Nagarajan, P. and Radha, N.V. 1999. Antibiotic supplementation as a component of integrated disease management in silkworm. Indian Silk, 2(4) 39-40.

Nagaraju, J. 2008. Silk of India, grace and luster. Biotechnol. News, 3: 4-7.

Rangaswamy, Sundarbabu, P.C., Govindan, R., Chinnaswamy, K.P., Aruna, K.P. 2003. Influence of lime against the control of white muscardine disease development in two silkworm breeds. In: Advances in Agricultural biotechnology, V.s. Harikumar (ed.), New Delhi, India. Regency Publications, pp. 149-152.

Samson, M.V., Baig, M. Sapru, M.L. and Narasimhanna, M.N. 1986. Efficacy of certain fungicides and disinfectants for the control of white muscardine disease in mulberry silk worm. Indian J. Seric., 25: 78-83.

Samson, M.V., Singh, R.N. and Sasidharan, T.O. 1998. Resham Jyothi- a wide spectrum bed disinfectant, Indian Silk, 37(3): 9-10.
Sashidharan, T.O., Singh, R.N., Samson, M.V., Daniael, A.G.K. and Rao, S.G. 1997. Efficiency of a new bed disinfectant Resham sanjeevini against incidence of disease in silkworm crops under field condition. Current Technology Seminar on Silkworm disease Management Rearing Technology and Mulberry Pathology, C. S. R. \& T. I., Berhampore, West Bengal. India. $23^{\text {rd }}-24^{\text {th }}$, July, Abstract pp. 2.

Seidavi, A., Bizhannia, A., Mawajpour, M., Mirhoseini, Z. and Ghanipoor, M. 2005. Investigation on necessity and methods of establishment of Sericultural cooperatives. Sericologia, 46: 169-182.

Sengupta, K., Kumar, P., Baig, M. and Govindan, S. 1990. Diseases of mulberry silkworm and their control. In Hand book on pest and disease control of mulberry and silkworm, ESCAP Publications, Bangalore, pp. 52-55.

Singhvi, N.R., Sharma, D.D. and Datta, R.K. 1996. Mulberry: a boon for social forestry. Indian Silk, 35: 51- 52.

Subba Rao, G., Chandra, A.K. And Bhattacharya, J. 1992. Effect of bleaching powder and lime against grasserie and muscardine diseases of the silkworm Bombyx mori L. Indian J. Seric., 31(1): 37-40.

\section{How to cite this article:}

Akhilesh Kumar Kulmitra, V.B. Sanath Kumar and Raje Gowda. 2017. In vitro Studies of Efficacy of Different Chemicals for Management of Fungal Disease (White Muscardine) and Bacterial Disease (Bacillus and Staphylococcus) in Silk Worm bombax mori L. Int.J.Curr.Microbiol.App.Sci. 6(7): 2512-2524. doi: https://doi.org/10.20546/ijcmas.2017.607.356 